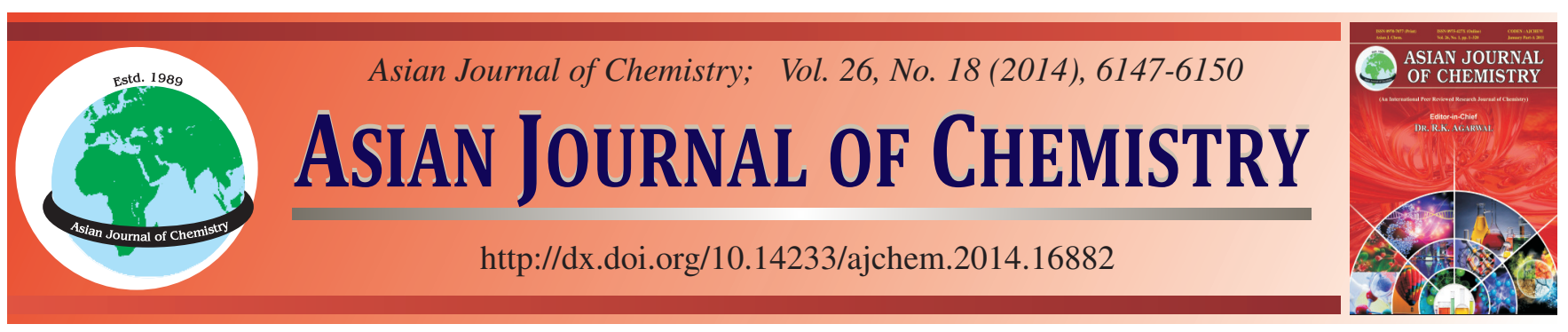

\title{
Effect of Municipal Solid Waste Compost on Leaching Heavy Metals (Chromium and Lead) into Soil
}

\author{
Ah. JonAidi JAFAri ${ }^{1}$, A. RAstegar ${ }^{2}$, M. FARZAdkia ${ }^{1}$, R. ReZaei KAlantary ${ }^{1}$ and A. RAhmani ${ }^{2}$
}

${ }^{1}$ Department of Environmental Health, Iran University of Medical Sciences, Tehran, Iran

${ }^{2}$ Department of Environmental Health Engineering, School of Public Health, Sabzevar University of Medical Sciences, Sabzevar, Iran

*Corresponding author: Fax: +98 571 2657800; E-mail: rastegar.89@gmail.com

\begin{abstract}
Compost of municipal solid waste may contain somewhat heavy metals concentrations which increase the concentration of metals in soil or groundwater. The main aim of this study was to consider the leaching of metals such as lead and chromium into two types of soil (sandy loamy soil, a sandy clay-loam soil) blended with contented compost in laboratory scale. The purred soils have spilled into columns. Treatments selected for this study were as: a: low metal content compost (LMCC), b: enriched metal content compost (EMCC), c: control. Subsequently, the soil columns were incubated at room temperature for 9 days and were irrigated daily with 250 mm de-ionized water. Leachates collected and analyzed for $\mathrm{pH}, \mathrm{EC}, \mathrm{pb}$ and $\mathrm{Cr}$ concentrations. The results showed that the application enriched metal content compost causes reducing $\mathrm{pH}$, increasing electrical conductivity and leakage of metals compared to the control in two soils .The concentration of metals in the leachates were depended on the soil characteristics and concentration metals existence in the compost added to the soil. Therefore, application of enriched metal content compost on the soils containing a high percentage of sand may created a risk in terms of groundwater contamination with heavy metals.
\end{abstract}

Keywords: Soil, Compost, Heavy metals.

\section{INTRODUCTION}

Soil is usually comprised from variety of materials such as minerals, solids, liquids, organic matters, air and microorganisms ${ }^{1}$. Mineral components of soil are composed of the physical changes and rocks erosion and its organic components are made from remains of plants and animals by fermentation ${ }^{2}$, which they have been decreased because of human activities and lapsing time $e^{3}$. Therefore, to increase soil fertility and environmental protection using some having humus materials such as compost of municipal solid wastes have been spreading in recent years because of its low-cost and high nutrients capability. Using of compost can increase the crop yield, a cation exchange capacity ${ }^{4}$ and reduces the erosion ${ }^{5}$. However composts may contain some heavy metals because of existing dyes, battery, electrical devices, cosmetic and pharmaceutical materials in the solid waste ${ }^{6,7}$. The most common metals that may involve in the compost are cadmium, chromium, copper and lead and their concentrations are variable from a part per million until a part per thousand ${ }^{6}$. With this description, application of compost may cause accumulating of heavy metals into soil layers, so it subsequently will probably contaminate the groundwater and surface waters ${ }^{8}$. Leaching heavy metals from compost into ground water can be hazardous for humankind and environment because of their toxicity and carcinogenetic ${ }^{9}$. The leaching rate of these heavy metals depended on their viability and mobility in the soil layers ${ }^{10}$. Also absorption or desorption of metals in the soil would vary by various factors such as $\mathrm{pH}$, oxidation potential, soil quality, concentration and kind of ion rival, organic or inorganic ligands, CEC capacity, oxidation and reduction potential, calcium carbonate and clay minerals concentrations, Fe-Mn oxidation and soil particle size $\mathrm{e}^{11-13}$. Furthermore other parameters such as ion exchange between soil particles and heavy metals induce decreasing of $\mathrm{pH}$ that this can affect on mobility of metals ${ }^{14}$. Ortiz and Alcaniz ${ }^{15}$ have demonstrated application of sludge on the soil caused declining of $\mathrm{pH}$ and so it would increase solubility of elements and transfer to the groundwater. Chen et al. ${ }^{16}$ has been showed that application of solid waste municipal compost on the red soil caused to transfer of almost $4 \%$ of copper and more than $58.3 \%$ of zinc of total copper and zinc. It has been reported that the cause of metal leakage is probably associated to metal combination with dissolved organic matters, also adding compost increases EC of soil ${ }^{17}$. Since utilizing of compost has been increased on agriculture soils in recent years, we aimed to study the leakage rate and 
TABLE-1

PHYSICAL AND CHEMICAL PROPERTIES OF THE SOILS BEFORE MUNICIPAL SOLID WASTE COMPOST APPLICATION

\begin{tabular}{ccccccccc}
\hline Soil (parent material) & $\begin{array}{c}\text { Sand } \\
(\mathrm{w} / \mathrm{w} \%)\end{array}$ & $\begin{array}{c}\text { Clay } \\
(\mathrm{w} / \mathrm{w} \%)\end{array}$ & $\begin{array}{c}\text { Silt } \\
(\mathrm{w} / \mathrm{w} \%)\end{array}$ & $\mathrm{pH}$ & $\begin{array}{c}\mathrm{EC}^{\mathrm{a}} 1: 5 \\
\mathrm{dS} \mathrm{m}^{-}\end{array}$ & $\begin{array}{c}\mathrm{OM}^{\mathrm{b}} \\
(\mathrm{w} / \mathrm{w} \%)\end{array}$ & $\begin{array}{c}\mathrm{Pb} \\
(\mathrm{mg} / \mathrm{kg})\end{array}$ & $\begin{array}{c}\mathrm{Cr} \\
(\mathrm{mg} / \mathrm{kg})\end{array}$ \\
\hline Sandy loam & 63 & 15.7 & 22.3 & 8.7 & 2.4 & 0.8 & 3.9 & 2.1 \\
Sandy Clay Loam & 61.7 & 33 & 5.3 & 8.4 & 3.9 & 2.4 & 15.6 & 3.7 \\
Silt Clay Loam & 17.7 & 38.9 & 43.9 & 7.1 & 5.3 & 10.1 & 1.4 & 0.5 \\
\hline A, EC = Electrical conductivity. B, OM = Organic matter content & & & & &
\end{tabular}

residual of lead and chromium after employing municipal solid waste compost on soils. Subsequently some factors including $\mathrm{pH}, \mathrm{EC}, \mathrm{Cr}$ and $\mathrm{Pb}$ concentrations were evaluated in both soil and leachate exhausted from column.

\section{EXPERIMENTAL}

Soils and composts: In this study, bulk samples of two soil were collected from Iran In this line, firstly concentration heavy metals determined in soils and compost. These samples comprised: sandy loam soil and sandy clay loam texture that had not previously been amended with composted solid waste. Before gathering, surface lawn and plant on soil omitted. Then a small pit with an area of 1.2 squares and depth of $1 \mathrm{~m}$ was created by a shovel. Then soil dried in the air and it was passed than a riddle of mesh 10 for uniformity and removal of coarse material. In order to assess the roles of the physical properties, fraction of soils in heavy metals transferred from soils were amended with composted solid waste Compost was purchased from factory of Kahrizakin Tehran, Capital of Iran. As regards the metal concentration compost was purchased low, so some of the compost was enriched by incubating it for $24 \mathrm{~h}$ with soluble $\mathrm{Pb}\left(\mathrm{NO}_{3}\right)$ and $\mathrm{K}_{2} \mathrm{Cr}_{2} \mathrm{O}_{7}$ after it was air-dried. Physical and chemical properties soils and compost have been described in the Tables 1 and 2 .

\section{TABLE-2}

$\mathrm{Pb}$ AND Cr CONTENT (AS MG OF METAL kg- PER DRY MATTER OF COMPOST) IN AQUA REGIA EXTRACTS OF THE COMPOST USED IN THIS STUDY AND RESTRICTIONS FOR COMPOST APPLICATION OF THE IRAN LEGISLATION

\begin{tabular}{ccc}
\hline Characteristic & LMCC $^{\mathrm{a}}$ & EMCC $^{\mathrm{b}}$ \\
\hline $\mathrm{pH}$ & 7.49 & 7.49 \\
$\mathrm{EC} 1: 5 \mathrm{dS} \mathrm{m}$ & 6.9 & 8.47 \\
$\mathrm{OM}(\%)$ & 13.7 & 13.7 \\
$\mathrm{~Pb}(\mathrm{mg} / \mathrm{kg})$ & 200 & 500 \\
$\mathrm{Cr}(\mathrm{mg} / \mathrm{kg})$ & 98 & 258 \\
\hline
\end{tabular}

A. Low metal content compost (LMCC). B, Enrich metal content compost (EMCC

Soil columns: Columns were prepared of polypropylene with an inner height of $1000 \mathrm{~mm}$ and an inner diameter of 110 $\mathrm{mm}$ and a plastic plate with tiny holes was placed in the bottom of column for steady flow of leachate. A paper filter was placed at the bottom of the column to prevent the removal of soil particles. The amount of soil for fill the column was calculated by density and volume of the column, then soil were gradually added onto column not operations certain compactness. Then, to keep a regular collapse of water on the soil column and to keep away from drops of water, dual plastic plates, every with 50 holes, were mounted on the top of the surface layer. Then water was poured on the columns in a period of the 9 days.
Distilled water with pH 6.5 and $1.07 \mu \mathrm{s} / \mathrm{cm}$ of electric conductivity was used the total volume of water was used for the column was $2250 \mathrm{~mL}$ (equal to $200 \mathrm{~mm}$ of rainfall) and divided into five aliquots with $250 \mathrm{~mL}$ each time. The leachate was collected and the $\mathrm{pH}, \mathrm{EC}, \mathrm{Pb}, \mathrm{Cr}$ analyzed. Before testing, the utensil was washed three times with diluted nitric acid $(3 \%$, $\mathrm{v} / \mathrm{v}$ ) and distilled water.

Elemental analysis: All analyses of metal content were done by atomic absorption Perkin Elmer model 3110 at Laboratory Centre, Tehran University of Medical Sciences. Also, pH was analyzed with HQ40D, USE.

Statistical analysis: All treatments were reiterated four times. Statistical tests were analyzed using SPSS. To compare the means, the data were subjected to ANOVA and SPEARMAN test. In all tables, mean values denoted by different letters are significantly different $(\mathrm{p}<0.05)$.

\section{RESULTS AND DISCUSSION}

Change of electrical conductivity in leachate: Fig. 1 show the alteration of electrical conductivity (EC) in the leachate for the period of 9 days of the experiment. Use of municipal solid waste compost on the soils induce increased electrical conductivity amount in the leachate for all soils in comparison with the controls (unlamented soils). Indeed, the electrical conductivity increases from 857 and $1020 \mu \mathrm{S} / \mathrm{cm}$ for the control soils to 1400 and $2440 \mu \mathrm{S} / \mathrm{cm}$ after incorporation compost LMCC and this amount increased to 2910 and 4130 $\mu \mathrm{S} / \mathrm{cm}$ because of application of enriched compost (EMCC). In the end of the experiment, electrical conductivity was still higher in treatments with EMCC but the increase was smaller. Addition compost on the soils induces increase of electrical conductivity, which was significant in all soils $(\mathrm{P} \leq 0 / 05)$. As the electrical conductivity of leachate increases, due to presence of more ions in the compost. Since processes involving ion replacement should have occurred and led to the raise in electrical conductivity. Similar results were observed by Kraschl et $a l .{ }^{18}$. Assefa et $a l .{ }^{19}$ showed that four annual applications of cattle manure on soils at a rate of $15 \mathrm{t} / \mathrm{ha}$ greater than before the electrical conductivity from 0.3 to $1.3 \mathrm{dS} / \mathrm{cm}$ increased. Courtney and Mullen ${ }^{20}$ confirmed that the application of two agro-industrial composts in loamy sandy soil increased significantly the soil electrical conductivity.

Changes in pH during experiments: During the experimentation, changes in the $\mathrm{pH}$ of leachate of the soils were experimented following the application of compost solid waste to the soils that shown in Fig. 2. Smallest amount was at the beginning of the test. An obvious decrease in $\mathrm{pH}$ was detected in the leachates by addition of $500 \mathrm{~mL}$ distilled water on the columns of the experiment were irrigated. In fact, the $\mathrm{pH}$ for the control soils decreases from 8.4 and 8.7 to 7.9 and 8 after 

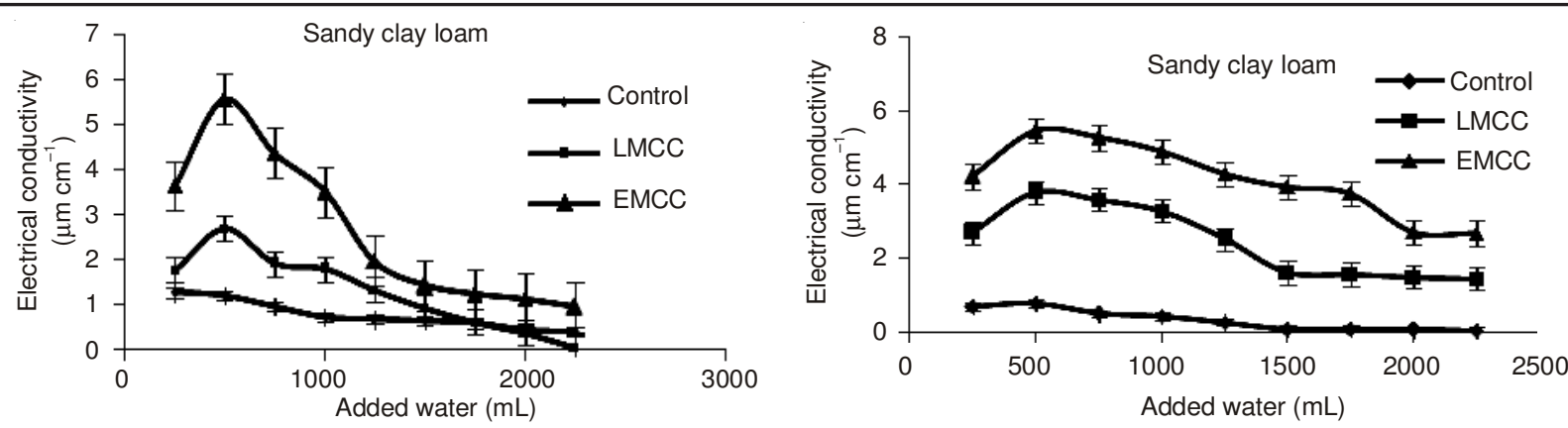

Fig. 1. Changes of electrical conductivity (EC) in leachates from soil columns in control soils and after municipal solid waste compost and metal enriched municipal solid waste compost addition to sandy clay loam soil, a sandy loam soil and an silt clay loam soil. Error bars refer to the standard error

incorporation of compost (LMCC) and a rate of decline to 7.7 and 7.8 by the use of compost contains more metals were observed. Fig. 2 shows that $\mathrm{pH}$ differences were significant between control sample and treatments which received compost on the two soils $(\mathrm{P} \leq 0 / 05)$. In fact, the $\mathrm{pH}$ decrease in compost amended columns could due to decomposition and the mineralization of the organic matter which increased the $\mathrm{CO}_{2}$ levels and decreased the $\mathrm{pH}$ of amended soils. Moreover, the $\mathrm{pH}$ changes were directly associated with the ion exchange in the soil columns among protons in soil particles and other captions such as heavy metal ions in compost also low molecular organic acids might be another matter participating in the ion exchange. The replaced low molecular organic acids were moving with the leachate, which existing lower acid in higher heavy metal treatments, which led to a decrease of $\mathrm{pH}$ in solution ${ }^{21}$. Other researchers have also reported the decrease of soil $\mathrm{pH}$ from 8.15 in a control treatment to 7.22 after the addition of composted sewage sludge at a rate of $160 \mathrm{t} / \mathrm{ha}^{20}$. Reportedly, the $\mathrm{pH}$ of a calcareous soil particularly decreased after 19 months the first application of organic material mix $^{22}$.

Heavy metals move from compost to leachates: The results showed that the simulated irrigation led to release of heavy metals: $\mathrm{Pb}$ and $\mathrm{Cr}$ in compost and removed from the column (Fig. 3). However, the concentrations of $\mathrm{Pb}$ and $\mathrm{Cr}$ in leachates were different during in this the study. A small amount of heavy metals was transferred from the compost to the leachate but a lot of more metals were removed from loamy sandy soil and with the addition of enriched metal content compost, leakage of metals in the leachate increased. The concentrations of $\mathrm{Pb}$ and $\mathrm{Cr}$ in the leachates of the columns were the highest in all studied soils but most differences were observed in the sandy loamy soil. The total concentration of $\mathrm{Pb}$ and $\mathrm{Cr}$ were 1786, 148 and 760, $55 \mu \mathrm{g} / \mathrm{L}$ from the water column soil sandy loamy mixed into compost (EMCC) and (LMCC), respectively.

It is cleared from Fig. 3 that amount of metal leakage from the column was negligible compared to the amount of total metals exist in compost. This could be due to physical and chemical properties of soils such as of high CEC, organic matter and high clay.

Because heavy metal can be absorbed by organic matter, silicates, or soil carbonates and finally, the reduced ability of metals from soill ${ }^{23}$. The role of carbonates in heavy metal retention has been pointed out by other authors and has been partly attributed to the formation of metal carbonates in soils ${ }^{24}$. These authors showed that removal of soil carbonates caused a marked decrease in absorption of heavy metal. Similarly, Toribio studied the leaching of $\mathrm{Zn}$ and $\mathrm{Cu}$ on two calcareous soils amended with sewage sludge. They also showed that carbonate is the most important soil element caught up in $\mathrm{Zn}$ and $\mathrm{Cu}$ retention ${ }^{25}$.

Residues of heavy metals in soil: Fig. 4 shows that the addition of compost increases the content of heavy metals in the surface soil layer and gradually decreases at lower depths. The results showed that the heavy metals $\mathrm{Pb}$ and $\mathrm{Cr}$ in the compost were mostly altered to the motionless form in the soil profile under the adding water conditions. There is significant difference between additional compost (LMSS) and compost (EMSS) $(\mathrm{p}<0.01)$, while there is insignificant difference between controls and treatment compost (CMSS) $(\mathrm{p}>$ 0.05). Among the two types of soil tested, the highest level of leached metals remained in sandy clay loamy. Because metals are linked with organic matter in compost. Also, humid materials in compost tend to increase throughout maturation and stabilization of heavy metals, thus lessening their availability, so metal movement decreased to lower layers. The study
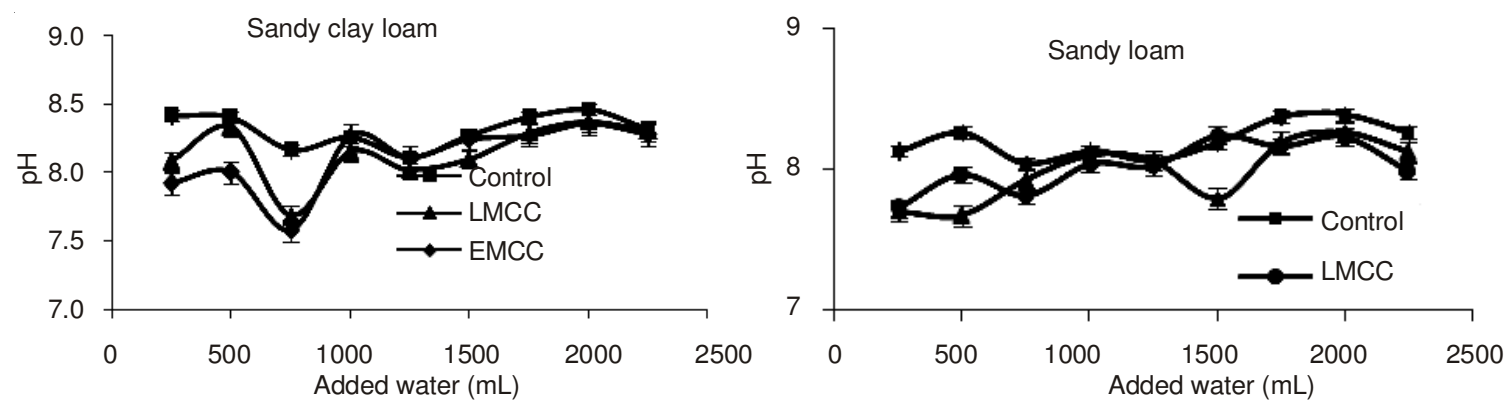

Fig. 2. Changes of $\mathrm{pH}$ in leachates from soil columns in control soils and after municipal solid waste compost and metal enriched municipal solid waste compost addition to a sandy clay loam soil and a sandy loam soil. Error bars refer to the standard error 


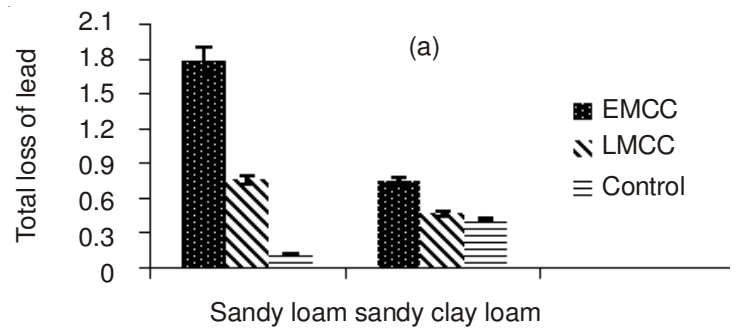

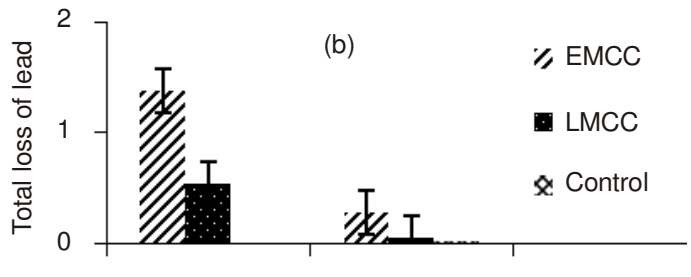

Sandy loam Sandy clay loam

Fig. 3. Total loss ( $\mu$ g metal/kg soil) of a: lead, b: chromium over 9 days irrigation applied to sandy loam and sandy clay loam (error bars $=$ one S.P)
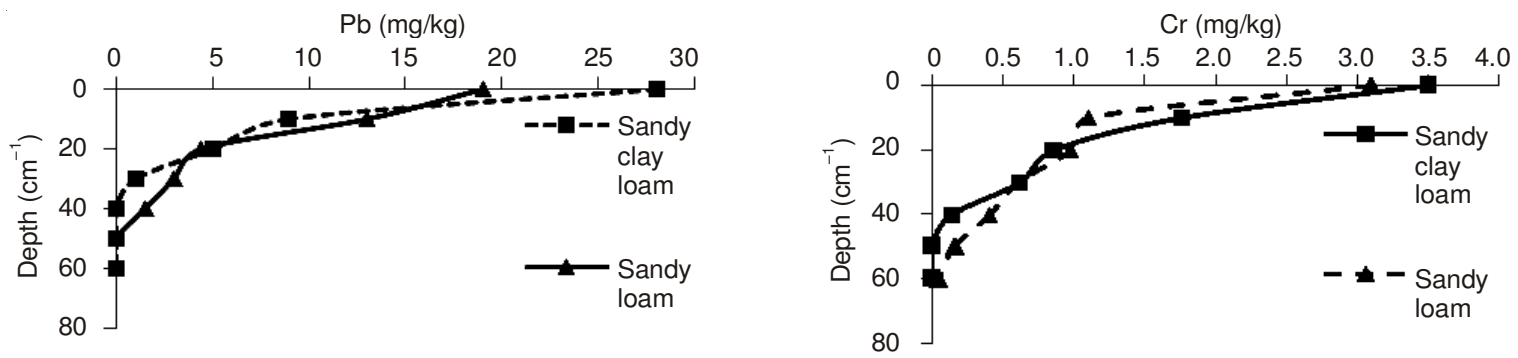

Fig. 4. Residual $\mathrm{Pb}$ and $\mathrm{Cr}$ content (as $\mathrm{mg}$ of metal $\mathrm{kg}^{-}$of soil) in aqua regia of the soils after of application of the EMCC

indicate that the amount of residual metals in alkaline soils was higher than in acid soil ${ }^{26,27}$.

\section{Conclusion}

Leaching of heavy metals in natural conditions was different from those in the laboratory when done in columns. Soil height was the main factor in natural conditions and it may be the best maintenance factor; but, preferential-flow paths can boost losses under natural conditions as well. However, watering and leakage is constant in laboratory columns and the amount of leakage is higher than normal. The results showed that use of municipal solid waste compost led to metals increase and they were significant in the surface soil. Heavy metal concentrations decreased in the lower layers, demonstrating that under the used watering system vertical movement of trace metals was not revealing in the studied. It is dependent on a number of factors which are related to the nature of the element, i.e. soil properties (e.g. $\mathrm{pH}$, electrical conductivity, clay content, organic matter rate), the type and quality of soil amendments ${ }^{1}$. As a result, the wastes that contain amounts of metals must be removed from the municipal waste prior to composting. Also, standards were determined for the type of soil that receives compost.

\section{ACKNOWLEDGEMENTS}

This study was funded and supported by Tehran University of Medical Sciences (TUMS).

\section{REFERENCES}

1. L.Q. Ren, J. Tong, J.-Q. Li and B.-C. Chen, J. Agric. Eng. Res., 79, 239 (2001)

2. J. Chen, H.-P. Blume and L. Beyer, Catena, 39, 121 (2000).
3. M. Jalali and H. Arfania, J. Plant Nutr. Soil Sci., 173, 407 (2010).

4. G. Vallini, A. Pera, M. Valdrighi and F. Cecchi, Water. Sci. Technol., 28, 229 (1993).

5. J.C. Hargreaves, M.S. Adl and P.R. Warman, J. Agric. Ecosyst. Environ., 123, 1 (2008)

6. S.R. Smith, J. Environ. Int., 35, 142 (2009).

7. E. Doelsch, A. Masion, G. Moussard, C. Chevassus-Rosset and O. Wojciechowicz, Geoderma, 155, 390 (2010).

8. M.J. Mohammad and B.M. Athamneh, J. Agron., 3, 229 (2004).

9. B. Jimanez, Int. Rev. Environ. Strateg., 6, 229 (2006).

10. A. Hosseinpour, GH. Haghnia, A. Alizadeh and A. Fotovat, J. Water Soil, 26, 563 (2008).

11. R.P. Narwal, B.R. Singh and B. Salbu, J. Commun. Soil Sci. Plant Anal., 30, 1209 (1999).

12. C. Kabala and B.R. Singh, J. Environ. Qual., 30, 485 (2001).

13. S. Chotpantarat, S.K. Ong, C. Sutthirat and K. Osathaphan, J. Environ. Sci. (China), 23, 640 (2011).

14. Z.-Y. Hseu, Chemosphere, 63, 762 (2006).

15. O. Ortiz and J.M. Alcañiz, Bioresour. Technol., 97, 545 (2006).

16. G. Chen, G. Zeng, C. Du, D. Huang, L. Tang, L. Wang and G. Shen, J. Hazard. Mater., 181, 211 (2010).

17. W.B. Achiba, N. Gabteni, A. Lakhdar, G.D. Laing, M. Verloo, N. Jedidi and T. Gallali, J. Agric. Ecosyst. Environ., 130, 156 (2009).

18. A. Kaschl, V. Römheld and Y. Chen, Sci. Total Environ., 291, 45 (2002).

19. B.A. Assefa, J. Schoenau and M.C.J. Grevers, Can. Biosyst. Eng., 46, 39 (2004).

20. R. Courtney and G. Mullen, Bioresour. Technol., 99, 2913 (2008).

21. H.E. Doner, Soil Sci. Soc. Am. J., 42, 882 (1978).

22. B. Foley and L.R. Cooperband, J. Environ. Qual., 31, 2086 (2002).

23. S. Chotpantarat, S.K. Ong, C. Sutthirat and K. Osathaphan, J. Environ. Sci. (China), 23, 640 (2011).

24. G. Ahlberg, O. Gustafsson and P. Wedel, Environ. Pollut., 144, 545 (2006).

25. M. Toribio and J. Romanya, Sci. Total Environ., 363, 11 (2006).

26. A. Chang, J. Warneke, A. Page and L. Lund, Environ. Quality, 13, 87 (1984).

27. Y.X. Chen, G.W. Zhu, G.M. Tian and H.L. Chen, Chemosphere, 53, 1179 (2003). 